Bulletin of Pharmaceutical Sciences
Assiut University
Website: http://bpsa.journals.ekb.eg/
e-mail: bullpharm@aun.edu.eg

\title{
PRE-SURGICAL USE OF MELATONIN AND ITS SIGNIFICANCE ON ENHANCING PROGNOSIS PROCESS IN PATIENTS UNDERGOING CARDIOPULMONARY BYPASS GRAFT
}

\author{
Reza Jouybar $^{1}$, Mansour Jannati ${ }^{2} *$ and Saeed Khademi ${ }^{1}$ \\ ${ }^{1} M D$, Anesthesiology and Critical Care Research Center, Shiraz University of Medical \\ Sciences, Shiraz, Iran \\ ${ }^{2}$ Cardiovascular Ward, Namazi Hospital, Shiraz University of Medical Sciences, Shiraz, Iran
}

\begin{abstract}
One treatment choice for patients with coronary artery disease is coronary artery bypass graft surgery (CABG) with cardiopulmonary bypass (CPB). After CABG, a series of inflammatory processes occur which affect other organs of the body and even cause severe organ damage and subsequently a worse prognosis. The purpose of this study was to evaluate the effect of pre-surgically administered Melatonin (MTN) on interleukins 22 and 13 in patients undergoing $C A B G$. In this clinical trial study, 22 patients were evaluated, 10 patients (45.5\%) in the MTN group, and 12 patients in the placebo group. The MTN group received $10 \mathrm{mg} /$ day of MTN and the placebo group received placebo 2 weeks before surgery. Serum interleukin 13 (IL13) and interleukin 22 (IL-22) levels were measured two weeks before surgery (T1), on the day of surgery before induction (T2), 6 hrs. after removal of the pump by the cardiac surgeon (T3), and 2 days after surgery (T4). The mean level of IL-22 at all time points in T2, T3, and T4 was significantly lower in the MTN group $(P<0.05)$. There was also a significant increase in IL-22 in both groups at T4 compared to T1. The levels of IL-13 were also decreased, however, in the MTN group, the difference was only significant at T2 compared to T1 for IL-13. The current study found that taking melatonin for two weeks before having CABG can help to minimize inflammation and inflammatory biomarkers including IL-22 and IL-13 after the procedure.
\end{abstract}

\section{INTRODUCTION}

Coronary artery bypass graft surgery (CABG) with cardiopulmonary bypass (CPB) is a treatment of choice for coronary artery disease ${ }^{1}$. Despite significant advances in anesthesia and $\mathrm{CABG}$ techniques, the mortality rates of these surgeries are still higher than many other surgeries ${ }^{2}$. CPB may activate oxidative stress and inflammatory response mostly because of the activation of polymorphonuclear leukocytes ${ }^{3 \& 4}$.

After CABG, a series of inflammatory processes occur and these stressors affect other organs of the body and even cause severe organ damage and subsequently a worse prognosis ${ }^{5}$. It is believed that activation of inflammatory processes is one of the pathogenesis of the reperfusion ischemia ${ }^{6}$.

Interleukins are cytokines made by a variety of white blood cells that often affect other lymphocytes ${ }^{7}$. They play an important role in the immune system and inflammation ${ }^{8}$. The role of interleukin-13 is to stimulate the growth and differentiation of B lymphocytes, inhibition of T1 helper lymphocyte (TH1) production, and inflammatory macrophage cytokine production. Interleukin-22 also plays an important role in the production of acutephase proteins ${ }^{9}$. Studies have shown that these interleukins levels increase after CABG and play a key role in systemic inflammation, immune response, and post-operative tissue damage $^{10}$. 
Melatonin (MTN) is a chemical substance of N-acetyl-5-methoxy-tryptamine and is secreted into the bloodstream and cerebrospinal fluid by tryptophan from the pineal gland ${ }^{11}$. It plays a significant role in regulating the biological clock and has antioxidant properties 12. There have been many studies about the beneficial effects of MTN on the cardiovascular system. It has a protective effect against ischemia by reducing sympathetic tone and rhythmic changes in heart rate, blood pressure, and cardiac output. It also increases collagen in myocardial ischemia-induced scarring through its direct effect on fibroblasts ${ }^{13 \& 14}$. MTN may play a role in reducing ventricular hypertrophy and preventing heart failure ${ }^{15}$. Supplementing with Melatonin reduced the severity of myocardial ischemia-reperfusion injury ${ }^{16}$.

Antioxidant and anti-inflammatory effects of MTN in the body increase defense immune system mechanisms ${ }^{17}$. It can be used as an antiinflammatory drug to boost the immune system $^{18}$. Because MTN is safe ${ }^{19}$, it is a choice antioxidant to reduce complications after cardiopulmonary bypasses such as inflammatory processes and oxidative stress ${ }^{20}$. It is shown that IL-22 was induced in cardiac surgery with $\mathrm{CPB}$ and it may interactively contribute to systemic inflammatory responses after $\mathrm{CPB}^{21}$. In a study, it is determined that IL13 may be involved in the development of coronary artery disease via different mechanisms under different conditions ${ }^{22}$.

Thus, if we can reduce the inflammatory processes caused by interleukins 13 and 22 by using melatonin, we can decrease the complications after cardiopulmonary bypass and coronary artery bypass graft surgery. Since there are practically a few methods to control the complications after coronary artery bypass graft surgery and little research has been done in this regard, it seems necessary to conduct this study. This study aims to evaluate the effect of pre-surgically administered MTN on inflammatory biomarkers including interleukins 22 and 13 in patients undergoing CABG.

\section{MATERIALS AND METHODS}

This clinical trial (RCT: 20141009019470N83) study was performed in
Namazi Hospital of Shiraz University of Medical Science, Shiraz, Iran. The study population was patients undergoing elective coronary artery bypass graft surgery.

According to statistical expert opinion and due to the lack of similar articles at the time of the study, this study was conducted as a pilot study with a sample size of at least 20 participants. The inclusion and exclusion criteria are mentioned in Table 1. Patients who were eligible to participate in the study were randomly and using a random number table divided into two groups after signing the written consent.

Table 1 : The inclusion and exclusion criteria

\begin{tabular}{|c|c|}
\hline Inclusion Criteria & Exclusion Criteria \\
\hline $\begin{array}{l}\text { Patients undergoing } \\
\text { elective coronary artery } \\
\text { bypass graft surgery }\end{array}$ & Kidney failure \\
\hline $\begin{array}{l}\text { Age between } 40 \text { and } 75 \\
\text { years }\end{array}$ & Pulmonary disease \\
\hline \multirow{13}{*}{$\begin{array}{l}\text { Having consented to } \\
\text { enter the study }\end{array}$} & Cerebrovascular disease \\
\hline & History of stroke \\
\hline & Liver failure \\
\hline & $\begin{array}{ll}\text { Using } & \text { the } \\
\text { immunosuppressant drug }\end{array}$ \\
\hline & $\begin{array}{l}\text { Dementia, depression, } \\
\text { mental illness }\end{array}$ \\
\hline & $\begin{array}{l}\text { Smoking more than } 5 \\
\text { packages per year }\end{array}$ \\
\hline & 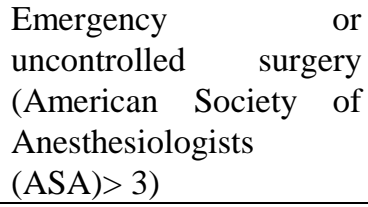 \\
\hline & Pregnancy or lactation \\
\hline & Anticoagulation \\
\hline & $\begin{array}{l}\text { Concomitant cardiac } \\
\text { surgery }\end{array}$ \\
\hline & $\begin{array}{l}\text { Left Ventricular (LV) } \\
\text { aneurysm }\end{array}$ \\
\hline & $\begin{array}{l}\text { Non-sinus rhythm in } \\
\text { electrocardiogram } \\
\text { (ECG), }\end{array}$ \\
\hline & $\begin{array}{l}\text { Ejection fraction less } \\
\text { than } 45 \%\end{array}$ \\
\hline
\end{tabular}

Two weeks before surgery, patients were admitted to the hospital and the necessary explanations were given by the resident. Then $5 \mathrm{cc}$ of blood (T1) was taken to measure serum levels of IL-13 and IL-22 and sent to the 
laboratory and stored at $-70^{\circ} \mathrm{C}$. The experimental group was asked to take 10 mg/day of MTN (Zahravi Pharmaceutical Company, Tabriz, Iran) 1 hour before bedtime, and a placebo ( $5 \%$ dextrose dissolved in water) was given to the control group ${ }^{16 \& 23}$. After 2 weeks of taking Melatonin and placebo, the second sample was taken on the surgery day before the induction of anesthesia (T2). Also, the third sample (T3) was taken 6 hrs. after removal of the pump by the cardiac surgeon (T3) and the fourth sample was collected 2 days after surgery (T4). All samples were stored in the laboratory refrigerator immediately after blood sampling was done. IL-13 and IL-22 levels were measured using the Human Th cytokine panel (13 plex) BioLegend USA kit, using a Bead Based assay.

\section{Statistical Analysis}

SPSS software version 19 was used for data analysis. Kolmogorov Smirnov test was used to check for normality. Student t-test, U Mann-Whitney, chi-square, and repeated measure tests were used to compare the variables between the two groups. Results were considered significant at $\mathrm{P}<0.05$.

\section{RESULTS AND DISCUSSION}

\section{Results}

In this study, 22 patients were evaluated, 10 patients $(45.5 \%)$ in the MTN group, and 12 patients $(54.5 \%)$ in the control group. Figure 1 shows the CONSORT diagram.

The mean age of patients was $60.22 \pm 6.36$ years. The demographic information of the patients is summarized in Table 2 .

The mean serum levels of IL-22 and IL-13 were similar between the two groups before intervention. Serum IL-22 levels in the second (T2), third (T3), and fourth (T4) samples were significantly different between the two groups (Table 3). The serum levels of IL-22 were significantly decreased in the MTN group after 2 weeks (Table 4, Figure 2).

According to the results in Table 5, no significant difference was observed in serum levels of IL-13 between the two groups in all 4 steps.

Like IL-22 after 2 weeks of MTN administration, serum IL-13 levels also decreased significantly. The trend of IL-13 changes is shown in Table 6 and Figure 3.

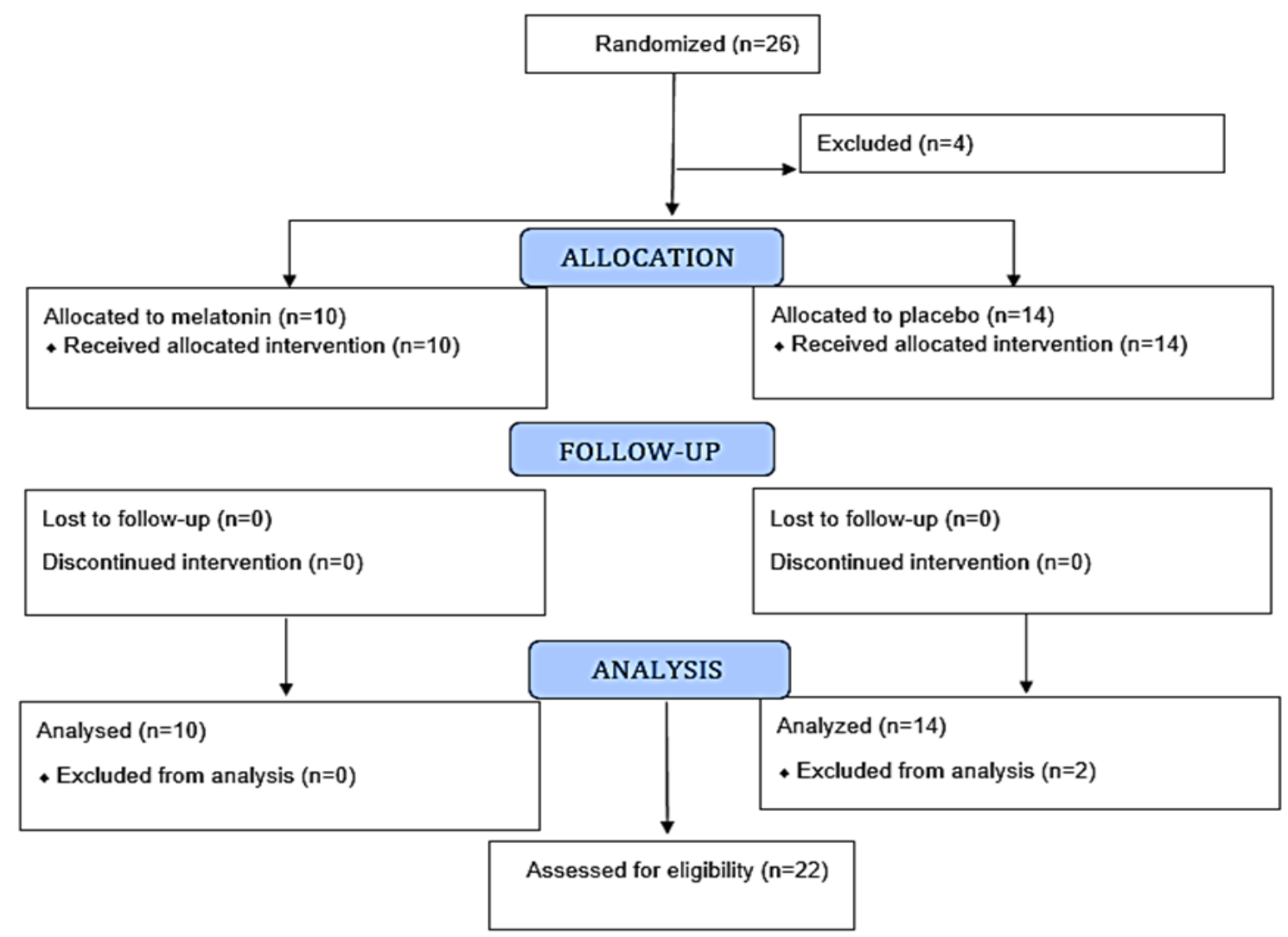

Fig. 1: CONSORT diagram 
Table 2 : Demographic information of patients

\begin{tabular}{|c|c|c|c||}
\hline Parameters & $\begin{array}{c}\text { Melatonin } \\
\mathbf{n = 1 0}\end{array}$ & $\begin{array}{c}\text { Control } \\
\mathbf{n = 1 2}\end{array}$ & P-value \\
\hline Age, $\mathbf{y}(\mathbf{m e a n} \pm$ SD) & $61.20 \pm 8.02$ & $59.41 \pm 4.79$ & $0.52^{*}$ \\
\hline Sex & & & $0.37^{* *}$ \\
\hline Male & $5(50 \%)$ & $9(75 \%)$ & \\
\hline Female & $5(50 \%)$ & $3(25 \%)$ & \\
\hline
\end{tabular}

* Student t-test

** Pearson Chi-Square test

Table 3 : Mean IL-22 levels in both groups

\begin{tabular}{|c|c|c|c|}
\hline IL-22 (ng/l) & Melatonin & Control & P-value \\
\hline IL-22 (T1) & $381.57 \pm 33.81$ & $379.37 \pm 15.88$ & 0.84 \\
\hline IL-22 (T2) & $364.31 \pm 16.97$ & $387.73 \pm 22.98$ & 0.01 \\
\hline IL-22 (T3) & $408.92 \pm 13.87$ & $434.53 \pm 17.04$ & 0.001 \\
\hline IL-22 (T4) & $402.12 \pm 17.10$ & $418.82 \pm 19.04$ & 0.04 \\
\hline P-value* & 0.03 & 0.001 & \\
\hline
\end{tabular}

*Repeated measure test result

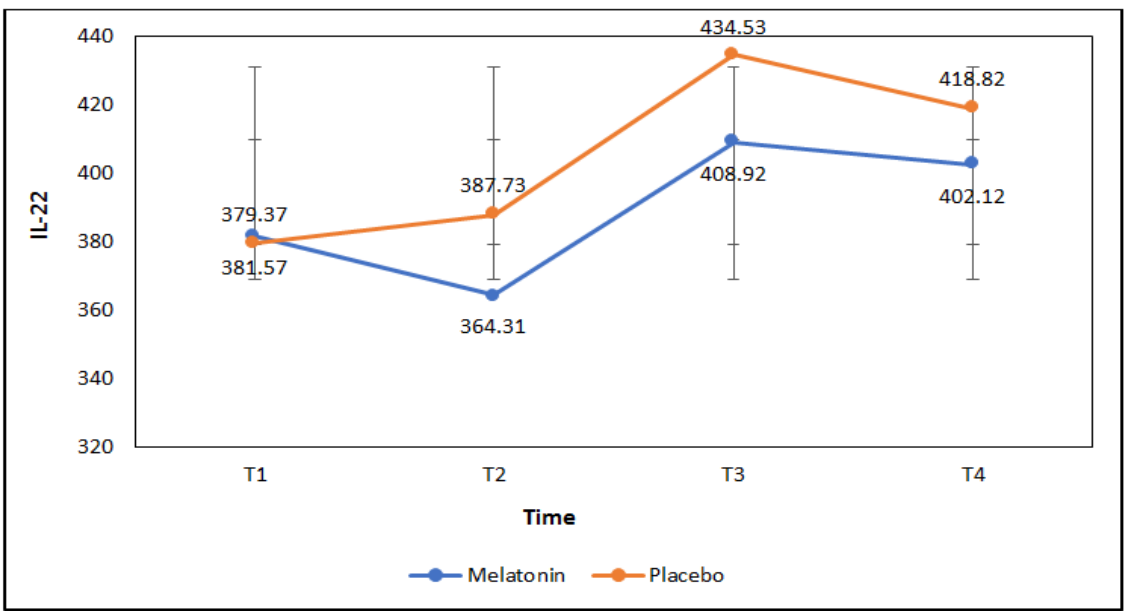

Fig. 2: Trends in IL-22 changes in Melatonin and placebo groups

Table 4 : The mean difference between the different IL-22 measurement steps

\begin{tabular}{||l|l|l|l|l|l|l|l|}
\hline \multicolumn{2}{|c|}{} & \multicolumn{2}{c|}{ T2 } & \multicolumn{2}{c|}{ T3 } & \multicolumn{2}{c|}{ T4 } \\
\cline { 3 - 8 } \multicolumn{2}{|c|}{ T1 } & Melatonin & Control & Melatonin & Control & Melatonin & Control \\
& $\begin{array}{l}\text { Mean } \\
\text { difference }\end{array}$ & -17.26 & 8.35 & 27.34 & 55.15 & 20.55 & 39.44 \\
\cline { 2 - 8 } P-value & 0.78 & 0.40 & 0.05 & $<0.001$ & 0.04 & $<0.001$ \\
\hline \multirow{3}{*}{ T2 } & $\begin{array}{l}\text { Mean } \\
\text { difference }\end{array}$ & & & 44.60 & 46.80 & 37.81 & 31.09 \\
\cline { 2 - 8 } & P-value & & & $<0.001$ & $<0.001$ & $<0.001$ & 0.001 \\
\hline \multirow{3}{*}{ T3 } & $\begin{array}{l}\text { Mean } \\
\text { difference }\end{array}$ & & & & & -6.79 & -15.70 \\
\cline { 2 - 8 } & P-value & & & & 0.37 & 0.07 \\
\hline
\end{tabular}


Table 5 : Mean IL-13 levels in both groups

\begin{tabular}{|c|c|c|c||}
\hline IL-13 (ng/l) & Melatonin & Control & P-value \\
\hline IL-13 (T1) & $14.25 \pm 6.55$ & $11.41 \pm 7.25$ & 0.35 \\
\hline IL-13 (T2) & $10.84 \pm 5.95$ & $10.89 \pm 6.50$ & 0.98 \\
\hline IL-13 (T3) & $15.03 \pm 6.13$ & $17.02 \pm 11.28$ & 0.64 \\
\hline IL-13 (T4) & $12.96 \pm 4.13$ & $15.06 \pm 7.49$ & 0.43 \\
\hline P value* & 0.12 & 0.05 & \\
\hline
\end{tabular}

Table 6: The mean difference between the different IL-13 measurement steps

\begin{tabular}{|c|c|c|c|c|c|c|c|}
\hline & \multicolumn{2}{|c|}{$\mathrm{T2}$} & \multicolumn{2}{|c|}{ T3 } & \multicolumn{2}{|c|}{ T4 } \\
\hline & & $\begin{array}{l}\text { Melatoni } \\
\text { n }\end{array}$ & Control & $\begin{array}{l}\text { Melatoni } \\
\text { n }\end{array}$ & Control & $\begin{array}{l}\text { Melatoni } \\
\text { n }\end{array}$ & Control \\
\hline \multirow[t]{2}{*}{ T1 } & $\begin{array}{l}\text { Mean } \\
\text { difference }\end{array}$ & -3.41 & -0.51 & 0.75 & 5.06 & -1.29 & 3.65 \\
\hline & P-value & 0.01 & 0.83 & 0.75 & 0.18 & 0.24 & 0.06 \\
\hline \multirow[t]{2}{*}{$\mathbf{T} 2$} & $\begin{array}{l}\text { Mean } \\
\text { difference }\end{array}$ & & & 4.54 & 5.76 & 2.12 & 4.17 \\
\hline & P-value & & & 0.06 & 0.04 & 0.06 & 0.09 \\
\hline \multirow[t]{2}{*}{ T3 } & $\begin{array}{l}\text { Mean } \\
\text { difference }\end{array}$ & & & & & -2.02 & -1.14 \\
\hline & P-value & & & & & 0.31 & 0.77 \\
\hline
\end{tabular}

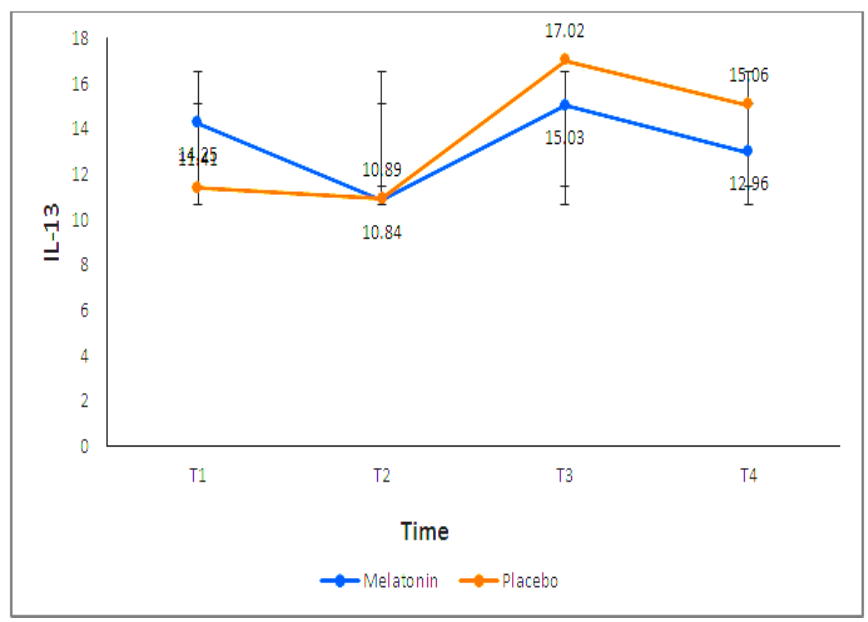

Fig. 3 : Trends in IL-13 changes in Melatonin and placebo groups

\section{Discussion}

In this study, the effect of MTN on interleukins 22 and 13 in patients undergoing coronary artery bypass graft surgery was evaluated.

In the present study, the two groups at the beginning of the study were matched for serum levels of interleukins 13 and 22 to compare the two groups correctly. On the day of surgery and before induction, serum IL-22 levels were significantly decreased in the MTN group, whereas in the control group serum IL-22 levels were not significantly changed. Given that they had taken MTN 2 weeks before surgery, the decrease in IL-22 was justified in this group. Also in the control group, no change in IL-22 was observed. There was also a significant difference between the two groups at this stage and the level of IL-22 in the MTN group was significantly lower.

In the third measurement step (T3), 6 hrs. after the pump was removed by the cardiac surgeon, both groups showed an increase in serum IL-22 
levels, which was significant in relation to $\mathrm{T} 2$ in both groups and T1 only in the MTN group.

In the fourth measurement, serum levels of IL-22 did not change significantly in the two groups compared to the third stage, but compared to the T1 stage, both groups showed a significant increase in T4. It can be argued that the acute phase of IL-22 occurs at T3 and reaches its maximum level after which its level has decreased but this reduction was not significant. Inter-group differences in the T4 level of IL-22 were also significantly higher in the control group than in the MTN group. Given that patients in the MTN group at the T3 stage also had lower IL-22, this is justified because no significant change in $\mathrm{T} 4$ over $\mathrm{T} 3$ was observed in either group.

In the present study, serum levels of IL-13 at $\mathrm{T} 1$ were similar between the two groups. But unlike IL-22, this cytokine did not show a significant difference between the two groups at all stages of $\mathrm{T} 2$ to $\mathrm{T} 4$. In the intra-group analysis in this study, IL-13 at T2 compared to T1 in the MTN group showed a decrease in IL13 level, which was significant. But no significant changes were observed in the control group. A non-significant increase in IL13 serum level was observed in T3 compared to $\mathrm{T} 2$ in both groups, which is justified since it is after CABG. There was a decrease in IL-13 in both groups at T4 compared to T3, which was not significant in either group.

It has been shown that the positive effects of MTN in ischemia-reperfusion damages are related to the activation of the Nrf2 pathway. Nrf2 is a transcription factor. It plays its antioxidant role by binding to DNA antioxidant response element (ARE) and the Nrf2-ARE pathway has an important protective effect in ischemia-reperfusion injury ${ }^{24}$. Nrf2 suppresses IL-13 and IL-22 secretion ${ }^{25 \& 26}$. IL-13 and IL22, upregulate the STAT3 pathway and cause inflammation $^{27 \& 28}$. By the decrease of IL-13 and IL-22, STAT3 is downregulated and prevents inflammation.

These changes in serum levels of cytokines after cardiac surgery have also been shown in other studies. Brull's study showed that 6 hrs. after CABG, serum IL-6 levels peaked. In that study, IL-6 levels reached 45 times their basal level, 6 hrs. after $\mathrm{CABG}^{29}$. In the present study, as in the Brull study, peak levels of both IL-22 and IL-13 were observed 6 h after CABG. In the study of Czerny et al., patients with CABG had the highest serum IL-6 and IL-10 levels at the fourth hour and eighth hrs. after CABG, respectively ${ }^{30}$. Nathan et al. evaluated the serum levels of IL-10, IL-4, and IL-13 in patients who had cardiopulmonary bypass (CPB). In that study, IL-10 peaked at the sixth hour after CPB. However, IL-13 peaked after $24 \mathrm{hrs}$. of CPB completion ${ }^{31}$. In the Sablotzki study, serum levels of IL-10 were highest in $\mathrm{CPB}$ patients at the skin closure stage after $\mathrm{CPB}$ completion. However, there was a significant decrease of $6 \mathrm{hrs}$. after $\mathrm{CPB}^{32}$. The findings of these two studies are not in line with ours. The main reason for this difference may be the difference in the study population and the type of surgery. A study by Kawamura et al. investigated the changes in IL-10, IL-8, and IL- 6 cytokines after aortic declamping. The results of this study showed that the peak of all three interleukins occurs $3 \mathrm{hrs}$. after aortic declamping ${ }^{33}$. Hsing et al. showed that levels of IL-22 and IL-19 peaked after 8 hrs. of CPB ${ }^{21}$. In the Wan study, it has been reported that the elevation of IL-10 begins 2 hrs. after CABG ${ }^{34}$. The pattern of IL-10 changes in this study is similar to the pattern of IL-22 changes in our control group. IL-22 is functionally similar to IL-10 in that the two cytokines are in the same group ${ }^{21}$, so the trend of changes in these two cytokines in the present study and the Wan study is justified. In Struber et al.'s study, serum IL-8 and IL-6 levels peaked at the eighth hour after CABG. C1-INH, TNF-R1, and TNF$\mathrm{R} 2$ cytokines were also measured in this study, all of which increased after CABG surgery and peaked within 2 to $8 \mathrm{hrs}$. after surgery ${ }^{35}$. Surgery causes a range of metabolic، endocrine, and immune alterations ${ }^{36}$. The inflammatory response in cardiac surgery is made by complex interactions with several pathways such as production or activation of complement, neutrophils, thrombin, cytokines ‘ mast cells, and some other multiple inflammatory mediators ${ }^{37}$. Mechanisms such as exposure of blood to nonphysiologic surfaces, anesthesia, trauma, body temperature alterations, and ischemia or reperfusion injury may be responsible for these pathological effects $^{38}$, which results in immunologic reactions and release proinflammatory cytokines، arachidonic acid metabolites, platelet-activating factors, endothelins, 
endothelial, and leukocyte adhesion molecules which induce the overproduction of reactive oxygen species ${ }^{39 \& 40}$.

In the study of Geyik et al., The effects of MTN levels on inflammatory function after CABG were compared. That study showed that preoperative, intraoperative, and 4 hrs.' postoperative serum MTN levels were significantly higher in patients who had surgery in the morning (group 1) than in patients who had surgery in the evening (group 2). Also in that study serum level of ICAM-1 was significantly higher in group 2 during and 4 hrs. after surgery. Given that ICAM-1 plays an important role in the development of inflammation in the body, it can be concluded that high MTN levels in CABG patients can have a protective effect on inflammation. MTN can reduce many undesirable disorders in patients with CABG. These effects are due to the antioxidant, anti-amyloid, and vasodilator effects of MTN ${ }^{41}$. In the study of Haghjooy et al., the effect of pre-CABG Melatonin administration on Nuclear Erythroid2-Related Factor 2 (Nrf2) activation was investigated. In this study, the Nrf2 level was significantly higher in all stages measured in the MTN group than in the placebo group. Nrf2 is a transcription factor responsible for the expression of many antioxidant response genes. Thus it can be said that MTN through the Nrf2 pathway can reduce the cellular damage induced by $\mathrm{CABG}^{24}$. During the inflammatory process, the stimulation of inflammationrelated genes can happen as a result of the activation of the nuclear transcription factorkappa B $(\mathrm{NF}-\kappa \mathrm{B})^{42}$. Many studies have revealed that MTN modulates the NF- $\mathrm{BB}$ signaling pathway throughout inflammation ${ }^{43-}$ 45. Reports recommend that MTN performs its anti-inflammatory effects by modulating both pro- and anti-inflammatory cytokines in various pathophysiological situations ${ }^{46 \& 47}$. It was displayed that the presence of melatonin receptors in a mast cell line by inhibiting the release of TNF- $\alpha$ modulates an antiinflammatory pathway ${ }^{48}$. Other antiinflammatory activities of MTN are including prevention from the synthesis of prostaglandins, production of adhesion molecules $^{49 \& 50}$, and downregulation of cyclooxygenase 2 expressions in macrophages $^{51}$, and the decrease of the polymorphonuclear cell recruitment to the inflammation location ${ }^{49 \& 52}$. MTN also counteracts inflammatory processes by scavenging free radicals, which contributes to inflammation $^{53-55}$.

\section{Conclusion}

It was shown that IL-22 induced in cardiac surgery with $\mathrm{CPB}$ and it may interactively contribute to systemic inflammatory responses after CPB. Also, IL-13 may be involved in the development of coronary artery disease via different mechanisms under different conditions. Thus, if we can reduce the inflammatory processes caused by interleukins 13 and 22 by using melatonin, we can decrease the complications after cardiopulmonary bypass and coronary artery bypass graft surgery. The current study found that taking melatonin for two weeks before having $\mathrm{CABG}$ can help to minimize inflammation and inflammatory biomarkers including IL-22 and IL-13 after the procedure.

\section{Ethical statement}

The study is approved by the ethics committee of Shiraz University of Medical Sciences with reference number IR.SUMS.MED.REC.1396.17. Written consent was obtained from participants. The study is performed according to the ethics principles of the Declaration of Helsinki.

\section{Limitation}

The small number of patients is a limitation of this study.

\section{Data Sharing Statement}

The necessary data are mentioned in the manuscript and any type of other data will be available upon request from the corresponding author at any time.

\section{REFERENCES}

1. G. A. Lee, "Determinants of quality of life five years after coronary artery bypass graft surgery", Heart Lung, 38 (2), 91-99 (2009).

2. E. D. Grech , N.J. Dodd ,M.J. Jackson, W.L. Morrison, E. B. Faragher, D.R. Ramsdale, "Evidence for free radical 
generation after primary percutaneous transluminal coronary angioplasty recanalization in acute myocardial infarction", Am J Cardiol, 77, 122-127 (1996).

3. E. Shafiei, M. Bahtoei, P. Raj, A. Ostovar, D. Iranpour, S. Akbarzadeh, et al., "Effects of $\mathrm{N}$-acetyl cysteine and melatonin on early reperfusion injury in patients undergoing coronary artery bypass grafting: A randomized, openlabeled, placebo-controlled trial", Medicine (Baltimore), 97(30), e11383 (2018).

4. M. Zakkar, G. Guida, M.S. Suleiman and G.D. Angelini, "Cardiopulmonary bypass and oxidative stress", Oxid Med Cell Longev, 2015, 189863 (2015).

5. W. Duan, Y. Yang, J. Yan, S. Yu, J.Liu, J. Zhou, et al, "The effects of curcumin posttreatment against myocardial ischemia and reperfusion by activation of the JAK2/STAT3 signaling pathway", Basic Res Cardiol, 107(3), 263 (2012).

6. K. Kawahito, H. Adachi and T. Ino, "Influence of surgical procedures on interleukin-6 and monocyte chemotactic and activating factor responses: $\mathrm{CABG}$ vs. valvular surgery", J Interferon Cytokine Res, 20, 1-6 (2000).

7. M. Akdis, S. Burgler, R. Crameri, T.Eiwegger, H. Fujita, E. Gomez, et al, 'Interleukins, from 1 to 37, and interferongamma: receptors, functions, and roles in diseases", J Allergy Clin Immunol, 127(3), 701-721 e1-70 (2011).

8. J.H. von der Thusen, J. Kuiper, T.J. van Berkel and E.A. Biessen, "Interleukins in atherosclerosis: molecular pathways and therapeutic potential", Pharmacol Rev, 55,133-166 (2003).

9. R.B. Rosen, D.N. Hu, M. Chen,S.A. McCormick, J. Walsh and J.S. Roberts, "Effects of melatonin and its receptor antagonist on retinal pigment epithelial cells against hydrogen peroxide damage", Mol Vis, 18, 1640-1648 (2012).

10. R. Vazan, D. Pancza, I. Beder and J. Styk, "Ischemia-reperfusion injury-antiarrhythmic effect of melatonin associated with reduced recovering of contractility", Gen Physiol Biophys, 24, 355-359 (2005).

11. M. Acikel, M.E. Buyukokuroglu, H. Aksoy, F. Erdogan and M.K. Erol, "Protective effects of melatonin against myocardial injury induced by isoproterenol in rats", J Pineal Res, 35, 7579 (2003).

12. C.E. Beyer, J.D. Steketee and D. Saphier, "Antioxidant properties of melatonin--an emerging mystery", Biochem Pharmacol, 56, 1265-1272 (1998).

13. A. Dominguez-Rodriguez, P. AbreuGonzalez and R.J. Reiter, "Clinical aspects of melatonin in the acute coronary syndrome", Curr Vasc Pharmacol, 7, 367 373 (2009).

14. R. Eli and J.A. Fasciano, "A chronopharmacological preventive treatment for sleep-related migraine headaches and chronic morning headaches: Nitric oxide supersensitivity can cause sleep-related headaches in a subset of patients", Med Hypotheses, 66, 461-465 (2006).

15. L. Girotti, M. Lago, O. Ianovsky, M.W. Elizari, A. Dini, S. Perez Lloret, et al, "Low urinary 6-sulfatoxymelatonin levels in patients with severe congestive heart failure", Endocrine, 22, 245-248 (2003).

16. K. H. Dwaich, F.G. Al-Amran, Bl. AlSheibani and H.A. Al-Aubaidy, "Melatonin effects on myocardial ischemia-reperfusion injury: Impact on the outcome in patients undergoing coronary artery bypass grafting surgery", Int $J$ Cardiol, 221, 977-986 (2016).

17. J. Mauriz, P.S. Collado, C. Veneroso, R.J. Reiter and J. Gonzalez-Gallego, "A review of the molecular aspects of melat onin's anti-inflammatory actions: recent insights and new perspectives", J Pineal Res, 54, $1-14$ (2013).

18. W.H. Zhang, J. Y. Li and Y. Zhou, "Melatonin abates liver ischemia/reperfusion injury by improving the balance between nitric oxide and endothelin", Hepatobiliary Pancreat Dis Int, 5, 574-579 (2006).

19. L.A. Erland and P.K. Saxena, "Melatonin Natural Health Products and Supplements: Presence of Serotonin and Significant 
Variability of Melatonin Content", J Clin Sleep Med, 13, 275-281 (2017).

20. G. D. Kim, S. E. Lee, T. H. Kim, Y. H. Jin, Y. S. Park and C. S. Park, "Melatonin suppresses acrolein-induced IL-8 production in human pulmonary fibroblasts", J Pineal Res, 52, 356-364 (2012).

21. C. H. Hsing, M. Y. Hsieh, W. Y. Chen, So.E. Cheung, B. C. Cheng and M. S. Chang, "Induction of interleukin-19 and interleukin-22 after cardiac surgery with cardiopulmonary bypass", Ann Thorac Surg, 81, 2196-2201 (2006).

22. L-F. Zha, S-F. Nie, Q-W. Chen, Y-H. Liao, H-S. Zhang, J-T. Dong, et al, "IL-13 may be involved in the development of CAD via different mechanisms under different conditions in a Chinese Han population", Scientific reports, 8, 1-8 (2018).

23. R. Jouybar, M. Setoodeh, Z.F. Saravi, S. Ahmadi, A. Karami, S. Khademi, et al, "The Effect of Melatonin on the Serum Level of Interleukin 6 and Interleukin 9 in Coronary Artery Bypass Grafting Surgery", Asian J Anesth, 58(1),3544(2020).

24. S. Haghjooy Javanmard, A. Ziaei, S. Ziaei, E. Ziaei and M. Mirmohammad-Sadeghi, "The effect of preoperative melatonin on nuclear erythroid 2-related factor 2 activation in patients undergoing coronary artery bypass grafting surgery", Oxid Med Cell Longev, 2013, 676829 (2013).

25. Y. Mitamura, M. Murai, C. Mitoma and M. Furue, "NRF2 Activation Inhibits Both TGF-beta1- and IL-13-Mediated Periostin Expression in Fibroblasts: Benefit of Cinnamaldehyde for Antifibrotic Treatment", Oxid Med Cell Longev, 2018, 2475047 (2018).

26. X. Lin, S. Gaudino, J. Kolls and P. Kumar, "Nrf2 selectively regulates IL-22 and IL-17A production in Th17 cells", $\boldsymbol{J}$ Immunol, 202181.7 (2019).

27. M. L. Nagalakshmi, A. Rascle, S. Zurawski, S. Menon and R. de Waal Malefyt R, "Interleukin-22 activates
STAT3 and induces IL-10 by colon epithelial cells", Int Immunopharmacol, 4, 679-691 (2004).

28. T. H. Pham, Y. Bak, J. W. Oh, J. Hong, S. Lee, J.T. Hong, et al, "Inhibition of IL-13 and IL-13Ralpha2 Expression by IL32theta in Human Monocytic Cells Requires PKCdelta and STAT3 Association", Int J Mol Sci, 20(8), 1949 (2019).

29. D. J. Brull, H. E. Montgomery, J. Sanders, S.Dhamrait, L. Luong, A. Rumley, et al., "Interleukin-6 gene $-174 \mathrm{~g}>\mathrm{c}$ and $-572 \mathrm{~g}>\mathrm{c}$ promoter polymorphisms are strong predictors of plasma interleukin-6 levels after coronary artery bypass surgery", Arterioscler Thromb Vasc Biol, 21, 14581463 (2001).

30. M. Czerny, H. Baumer, J. Kilo, A. Lassnigg, A. Hamwi, T. Vukovich, et al, "Inflammatory response and myocardial injury following coronary artery bypass grafting with or without cardiopulmonary bypass", Eur J Cardiothorac Surg, 17, 737-742 (2000).

31. N. Nathan, P. M. Preux, P. Feiss and Y. Denizot, "Plasma interleukin-4, interleukin-10, and interleukin-13 concentrations and complications after coronary artery bypass graft surgery", $\boldsymbol{J}$ Cardiothorac Vasc Anesth, 14, 156-160 (2000).

32. A. Sablotzki, I. Welters, N. Lehmann, T. Menges, G. Gorlach, M. Dehne, et al, "Plasma levels of immunoinhibitory cytokines interleukin-10 and transforming growth factor-beta in patients undergoing coronary artery bypass grafting", Eur $\boldsymbol{J}$ Cardiothorac Surg, 11, 763-768 (1997).

33. T. Kawamura, R. Wakusawa and K. Inada, "Interleukin-10 and interleukin-1 receptor antagonists increase during cardiac surgery", Can J Anaesth, 44, 38-42 (1997).

34. S. Wan, A. Marchant, J. M. DeSmet, M. Antoine, H. Zhang, J. L. Vachiery, et al, "Human cytokine responses to cardiac transplantation and coronary artery bypass 
grafting", J Thorac Cardiovasc Surg, 111, 469-477 (1996).

35. M. Struber, J.T. Cremer, B. Gohrbandt, C. Hagl, M. Jankowski, B. Volker, et al, "Human cytokine responses to coronary artery bypass grafting with and without cardiopulmonary bypass", Ann Thorac Surg, 68, 1330-1335 (1999).

36. M. Sander, C. von Heymann, V. von Dossow, C. Spaethe, W.F. Konertz, U. Jain, et al., "Increased interleukin-6 after cardiac surgery predicts infection", Anesthesia \& Analgesia, 102, 1623-1629 (2006).

37. S. Wan, J- L. LeClerc, J- L. Vincent, "Inflammatory response to cardiopulmonary bypass: mechanisms involved and possible therapeutic strategies", Chest, 112, 676-692 (1997).

38. M. M. Elahi, J.S. Khan and B.M. Matata, "Deleterious effects of cardiopulmonary bypass in coronary artery surgery and scientific interpretation of off-pump's logic", Acute cardiac care, 8, 196-209 (2006).

39. B.M. Matata, A.W. Sosnowski and M. Galiñanes, "Off-pump bypass graft operation significantly reduces oxidative stress and inflammation", Ann Thorac Surg, 69, 785-791 (2000).

40. B.M. Matata and M. Galiñanes, "Cardiopulmonary bypass exacerbates oxidative stress but does not increase proinflammatory cytokine release in patients with diabetes compared with patients without diabetes: regulatory effects of exogenous nitric oxide", $\boldsymbol{J}$ thorac cardiovasc surg, 120, 1-11 (2000).

41. S. Geyik, R. Yigiter, A. Akcali, H. Deniz, A. Murat Geyik, M. Ali Elci, et al, "The Effect of Circadian Melatonin Levels on Inflammation and Neurocognitive Functions Following Coronary Bypass Surgery", Ann Thorac Cardiovasc Surg, 21, 466-473 (2015).

42. M. Maze and W. Tranquilli, "Alpha-2 adrenoceptor agonists: defining the role in clinical anesthesia", Anesthesiology (Philadelphia), 74, 581-605 (1991).
43. A. Korkmaz, S. Rosales-Corral and R.J. Reiter, "Gene regulation by melatonin linked to epigenetic phenomena", Gene, 503, 1-11 (2012).

44. S. Cuzzocrea and R.J. Reiter, "Pharmacological action of melatonin in shock, inflammation and ischemia/reperfusion injury", European journal of pharmacology, 426, 1-10 (2001).

45. J. Vriend and R.J. Reiter, "Melatonin as a proteasome inhibitor. Is there any clinical evidence?", Life sciences, 115, 8-14 (2014).

46. S. Habtemariam, M. Daglia, A. Sureda, Z. Selamoglu, M. Fuat Gulhan and S. Mohammad Nabavi, "Melatonin and respiratory diseases: a review", Current topics in medicinal chemistry, 17, 467488 (2017).

47. G-M. Yu, H. Kubota, M. Okita and T. Maeda, "The anti-inflammatory and antioxidant effects of melatonin on LPSstimulated bovine mammary epithelial cells", PLoS One, 12, e0178525 (2017) .

48. A. Carrillo-Vico, S. García-Mauriño, J.R. Calvo and J.M. Guerrero, "Melatonin counteracts the inhibitory effect of PGE2 on IL-2 production in human lymphocytes via its mt1 membrane receptor", The FASEB Journal, 17, 755-757 (2003).

49. S. Cuzzocrea and R.J Reiter, "Pharmacological actions of melatonin in acute and chronic inflammation", Curr Top Med chem, 2, 153-165 (2002).

50. S. Cuzzocrea, T.P. Misko, G. Costantino, E. Mazzon, A. Micali, A.P. Caputi, et al, "Beneficial effects of peroxynitrite decomposition catalyst in a rat model of splanchnic artery occlusion and reperfusion", The FASEB Journal, 14, 1061-1072 (2000).

51. R. Hardeland, D.P. Cardinali, V. Srinivasan, D. W. Spence, G.M. Brown and S.R. Pandi-Perumal, "Melatonin-A pleiotropic, orchestrating regulator molecule", Prog Neurobiol,93, 350-384 (2011). 
52. J. K. LLOYD, "The importance of vitamin E in human nutrition", Acta Padiatr, 79, 6-11 (1990).

53. J. Espino, J. A. Pariente and A.B. Rodríguez, "Oxidative stress and immunosenescence: therapeutic effects of melatonin", Oxid Med Cell Longev, 2012,670294 (2012).
54. A. K. Ghosh, S. Naaz, B. Bhattacharjee, N. Ghosal, A. Chattopadhyay, S. Roy, et al., "Mechanism of melatonin protection against copper-ascorbate-induced oxidative damage in vitro through isothermal titration calorimetry", Life sci, 180, 123-136 (2017).

55. R. J. Reiter, J. C. Mayo, D. X. Tan, R. M. Sainz, M. Alatorre-Jimenez and L. Qin, "Melatonin as an antioxidant: under promises but over delivers", $J$ 


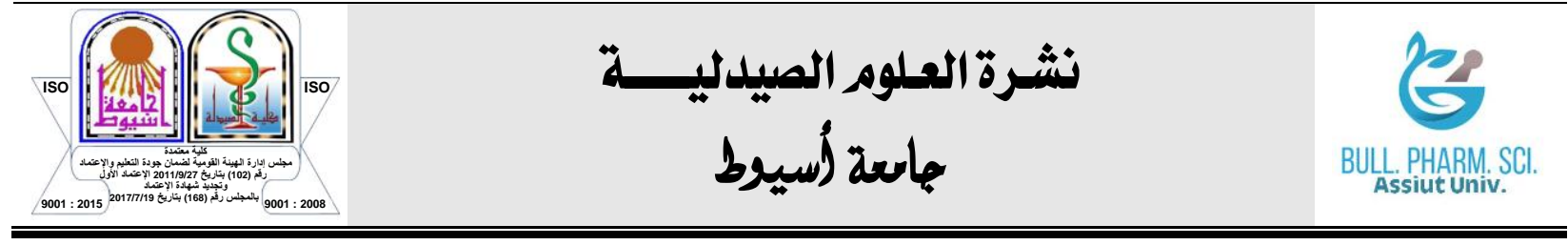

استخدام الميلاتونين قبل الجراحة وأهميته في تعزيز مآل الحالة في المرضى الذين

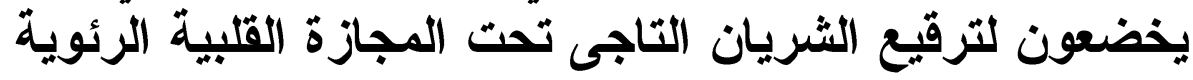

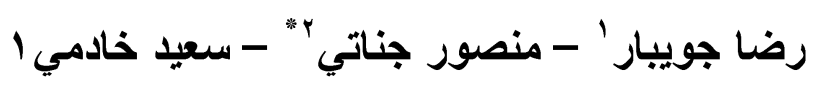

' مركز أبحاث التخدير والرعاية الحرجة ، جامعة شيراز للعلوم الطبية ، شيراز ، إيران

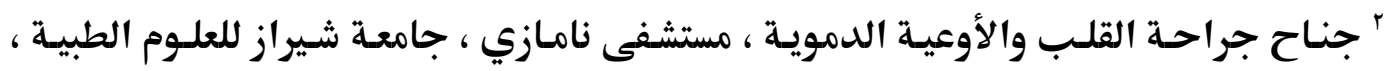

$$
\text { شيراز ، إيران، مصر جراحه }
$$

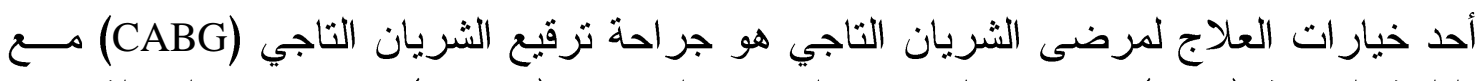

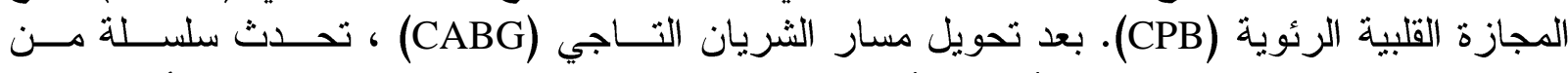

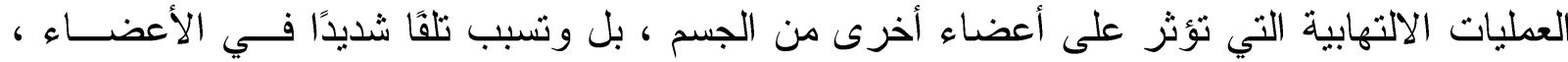

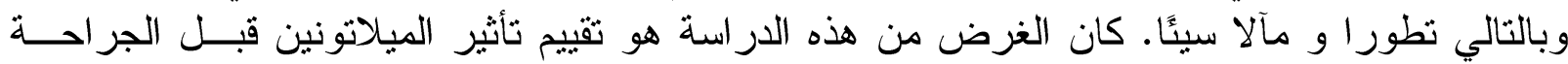

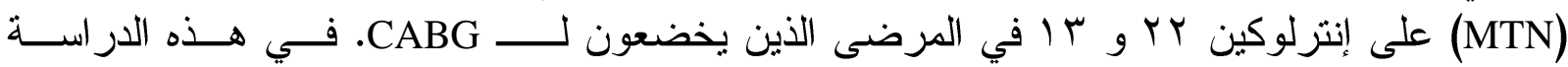

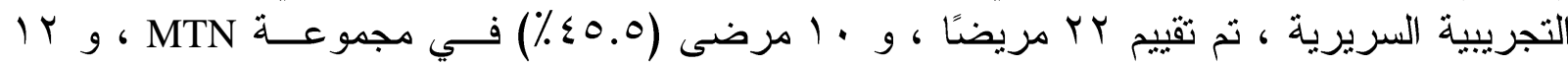

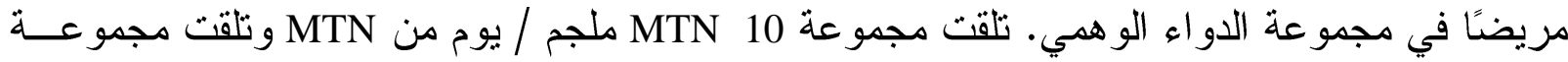

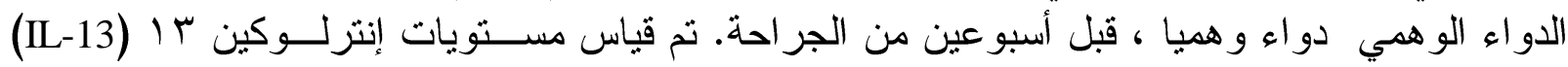

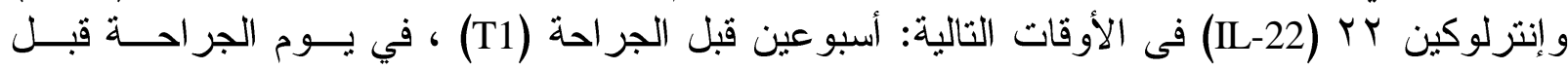

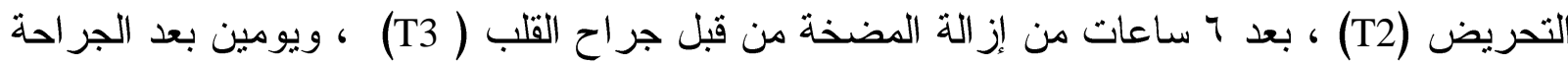

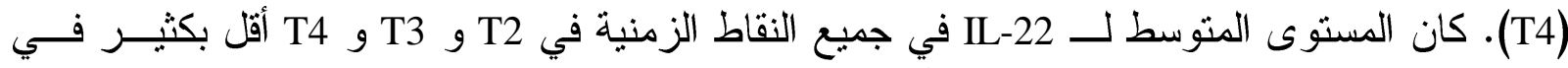

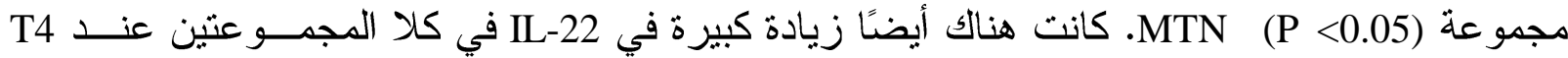

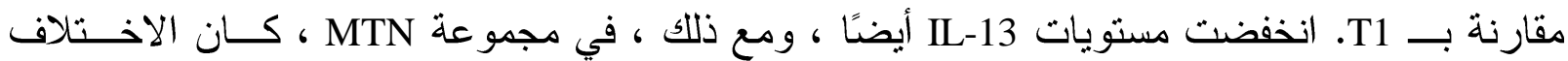

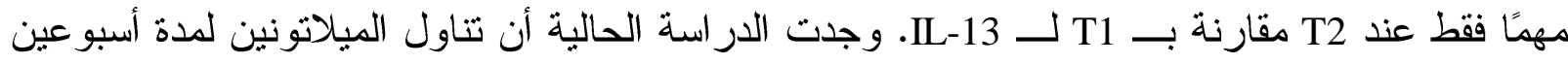

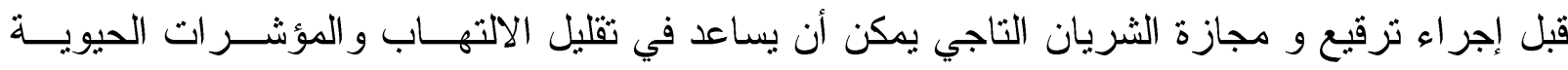

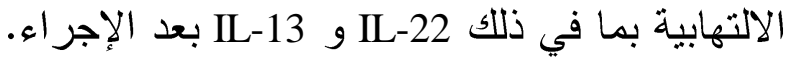

